\title{
New Chronological Constraints from Hypogean Deposits for Late Pliocene to Recent Morphotectonic History of the Alpi Apuane (NW Tuscany, Italy)
}

\author{
Ilaria Isola ${ }^{1,2, *}$, Francesco Mazzarini ${ }^{1}$, Giancarlo Molli ${ }^{3}$, Leonardo Piccini ${ }^{4} \mathbb{D}_{\text {, Elena Zanella }}{ }^{5}$, \\ Giovanni Zanchetta ${ }^{3}$, Russell Drysdale ${ }^{6}{ }^{\mathbb{D}}$, John Hellstrom ${ }^{7}$, Jon Woodhead ${ }^{7}$, Adriano Roncioni ${ }^{8}$, \\ Flavio Milazzo ${ }^{9}$, Diego Pieruccioni ${ }^{10}$ (D) and Eleonora Regattieri ${ }^{2}$
}

check for updates

Citation: Isola, I.; Mazzarini, F.; Molli, G.; Piccini, L.; Zanella, E.; Zanchetta, G.; Drysdale, R.; Hellstrom, J.; Woodhead, J.; Roncioni, A.; et al. New Chronological Constraints from Hypogean Deposits for Late Pliocene to Recent Morphotectonic History of the Alpi Apuane (NW Tuscany, Italy). Geosciences 2021, 11, 65. https:// doi.org/10.3390/geosciences11020065

Academic Editor: Jesus Martinez-Frias Received: 18 December 2020

Accepted: 28 January 2021

Published: 2 February 2021

Publisher's Note: MDPI stays neutral with regard to jurisdictional claims in published maps and institutional affiliations.

Copyright: (c) 2021 by the authors. Licensee MDPI, Basel, Switzerland. This article is an open access article distributed under the terms and conditions of the Creative Commons Attribution (CC BY) license (https:/ / creativecommons.org/licenses/by/ $4.0 /)$.
1 Istituto Nazionale di Geofisica e Vulcanologia Sezione di Pisa, 56125 Pisa, Italy; francesco.mazzarini@ingv.it 2 Istituto Geoscienze e Georisorse CNR, 56127 Pisa, Italy; eleonora.regattieri@igg.cnr.it

3 Dipartimento di Scienze della Terra, University of Pisa, 56126 Pisa, Italy; giancarlo.molli@unipi.it (G.M.); giovanni.zanchetta@unipi.it (G.Z.)

4 Department of Earth Science, University of Florence, 50121 Firenze, Italy; leonardo.piccini@unifi.it

5 Dipartimento di Scienze della Terra, University of Torino, 10125 Torino, Italy; elena.zanella@unito.it

6 School of Geography, The University of Melbourne, 3053 Melbourne, Australia; rnd@unimelb.edu.au

School of Earth Sciences, The University of Melbourne, 3053 Melbourne, Australia;

j.hellstrom@unimelb.edu.au (J.H.); jdwood@unimelb.edu.au (J.W.)

8 Gruppo Speleologico Lucchese, 55100 Lucca, Italy; a.roncioni59@gmail.com

9 Dipartimento di Scienze Chimiche della Vita e della Sostenibilità Ambientale, University of Parma, 43124 Parma, Italy; flavio.milazzo@studenti.unipr.it

10 Dipartimento per il Servizio Geologico d'Italia, ISPRA, 00144 Roma, Italy; diego.pieruccioni@isprambiente.it

* Correspondence: ilaria.isola@ingv.it

\begin{abstract}
A sedimentary sequence of fluvial deposits preserved in the Corchia Cave (Alpi Apuane) provides new chronological constraints for the evolution of the cave system and the timing and rate of uplift of this sector of the Alpi Apuane since the late Pliocene. Supported by magnetostratigraphic analysis performed on fine-grained fluvial deposits, and by radiometric dating of speleothems, we suggest that the deposition of fluvial sediments occurred between $1.6-1.2 \mathrm{Ma}$. This implies that the host volume of rock was already located close to the local base level, adding key information about the recent tectonic evolution of the Alpi Apuane. A few before $1 \mathrm{Ma}$, an erosive phase occurred due to the base-level lowering, followed by continuous speleothem deposition since at least $0.97 \mathrm{Ma}$. From that time, Monte Corchia uplifted at a maximum rate of $\sim 0.5 \mathrm{~mm} /$ year, which is consistent with isostatic uplift mainly driven by erosional unloading. The petrographical study of the fluvial deposits highlights the presence of material derived from the erosion of rocks that today are absent in the cave's catchment area, suggesting a different surface morphology during the Early Pleistocene. This study highlights the potential of cave sediments as archives for reconstructing the uplift history of mountain ranges.
\end{abstract}

Keywords: geochronology; karst; magnetostratigraphy; Corchia Cave; Alpi Apuane

\section{Introduction}

The Alpi Apuane (northwestern Italy) is a key area for understanding the morphological and tectonic evolution of the inner northern Apennines. A number of studies investigated the complex tectonic evolution of the region (e.g., [1-3] and reference therein), including the exhumation history and its relationship with the orogenesis of this sector of the Apennine chain, mainly through thermochronology methods (e.g., [4-8]). Thermochronology is the quantitative study of the thermal history of rocks using temperaturesensitive radiometric dating [9]. It is widely used to reconstruct rock exhumation rates and the tectonic evolution of mountain belts. 
Other chronological constraints on paleotectonic evolution of mountain ranges can be provided by alluvial deposits preserved in river terraces located at different altitudes, but their formation is often strongly affected by climate variations, and so they are not directly related to tectonically induced base-level changes and their chronology is, however, difficult to be defined in detail. Conversely, cave systems are less climate dependent than river systems because their evolution is usually slower and less controlled by surface processes [10]. Therefore, caves can provide additional quantitative constraints on the vertical displacement of a subterranean hydrologic system relative to its base level [11-14]. The erosional forms of cave passages, as well as the occurrence and nature of infill deposits, provide valuable information about the processes of their formation [15,16]. Moreover, since caves are one of the most stable continental environments, they can preserve depositional records for long periods.

Horizontal/sub-horizontal levels of passages not controlled by litho-structural horizons are considered the product of a stationary paleo-water table, while vertical sections are commonly formed as a consequence of a base-level fall $[10,17,18]$. The ages of these developmental stages can be inferred by dating the hypogean deposits using, for example, uranium-series geochronology or paleomagnetism, from which rock valley incision rates and regional paleogeographic evolution can be inferred ([19-21] and reference therein, [13-22]).

The Alpi Apuane are a prominent massif that reaches elevations of almost $2000 \mathrm{~m}$ a.s.l., only a few kilometres inland from the coastline, creating a barrier to the humid westerly air masses of North Atlantic provenance and generating precipitation exceeding $2500 \mathrm{~mm} /$ year [23]. These characteristics, along with the presence of extensive carbonate rock outcrops, support intense karst processes, allowing the formation of hundreds of caves [24]. The Corchia Cave karst system is the longest and most complex cave in the Alpi Apuane [25], and it developed in several sub-horizontal levels connected by pits or deep canyon-like passages, revealing at least three phases of base-level stillstand $[25,26]$. We describe here fluvial deposits preserved within the Galleria delle Stalattiti (GdS), which belongs to one of the major horizontal passage systems of the Corchia Cave complex. $\mathrm{U}-\mathrm{Pb}$ ages and paleomagnetic data acquired on samples of these deposits provide further constraints for the recent morphotectonic history of this sector of the Alpi Apuane.

\section{Geological Setting}

\subsection{The Alpi Apuane and the Monte Corchia}

The Apennine chain is a fold-and-thrust belt formed by thrusting from west to east of part of the Ligurian-Piedmont Ocean (Ligurian and Sub-Ligurian domain) over the Adria continental margin plate (Tuscan domain) during the Tertiary [27,28]. The deepest part of the Northern Apennine chain is exposed in the tectonic window of the Alpi Apuane ([1,29,30] and reference therein) (Figure 1), where two main tectono-metamorphic units, the Massa and the Apuane, outcrop. The former, exposed in the western part, experienced a higher degree of metamorphism and includes a Variscan basement and an upper Permian-Upper Triassic cover [3]. The latter, metamorphosed to greenschist facies, consists of a Paleozoic basement and metavolcanics of the early Permian age [31,32], unconformably covered by a Triassic-to-Oligocene sequence. The metasedimentary succession begins with Triassic continental to shallow-water deposits (Verrucano) followed by an Upper TriassicLower Jurassic carbonate sequence consisting of metadolostone (Grezzoni), metabreccia (Brecce di Seravezza), dolomitic marble, and marble. The sequence continues upward with Lower Jurassic-Lower Cretaceous cherty metalimestones, cherts, and calcschists. During the Lower Cretaceous-lower Oligocene, a progressive drowning of the carbonate platform allowed the sedimentation of phyllites and calcschists with marble interbeds. The sequence ends in the Oligocene-early Miocene with the deposition of turbiditic metasandstone (Pseudomacigno) ([33] and reference therein).

The Alpi Apuane are surrounded and structurally overlain by the Tuscan Unit, a Late Triassic-early Miocene carbonate and graywacke sequence, which experienced anchizonal 
metamorphism $[3,34]$, and tectonically overlain by the non-metamorphic Ligurian Units composed of Jurassic ophiolites and Jurassic-Paleogene sedimentary rocks. The structure of the Alpi Apuane is commonly interpreted as being due to two main tectono-metamorphic regional events: the D1 event, leading to a large-scale northeast-facing isoclinal fold stacking at the metamorphic peak conditions $[1,35]$, and the following D2, which was responsible for the progressive uplift and exhumation of the dome-like structure and the development of low-angle detachments [1-3]. The latest stages of D2 were associated with high-angle brittle faults mainly localized at the boundary between the Alpi Apuane and the surrounding Lunigiana/Versilia and Garfagnana tectonic depressions. Brittle deformation within the metamorphic core is expressed by localized and low-displacement, high-angle strike-slip to normal faults [3,36,37].

Monte Corchia is located in the southeast part of the Alpi Apuane Metamorphic Complex. According to Carmignani and Giglia [38], the Mt. Corchia structure is the result of a polyphase deformation during which an originally non-cylindrical eastwardfacing D1 overtuned syncline was refolded up to the present geometry, giving a locally downward-younging direction.

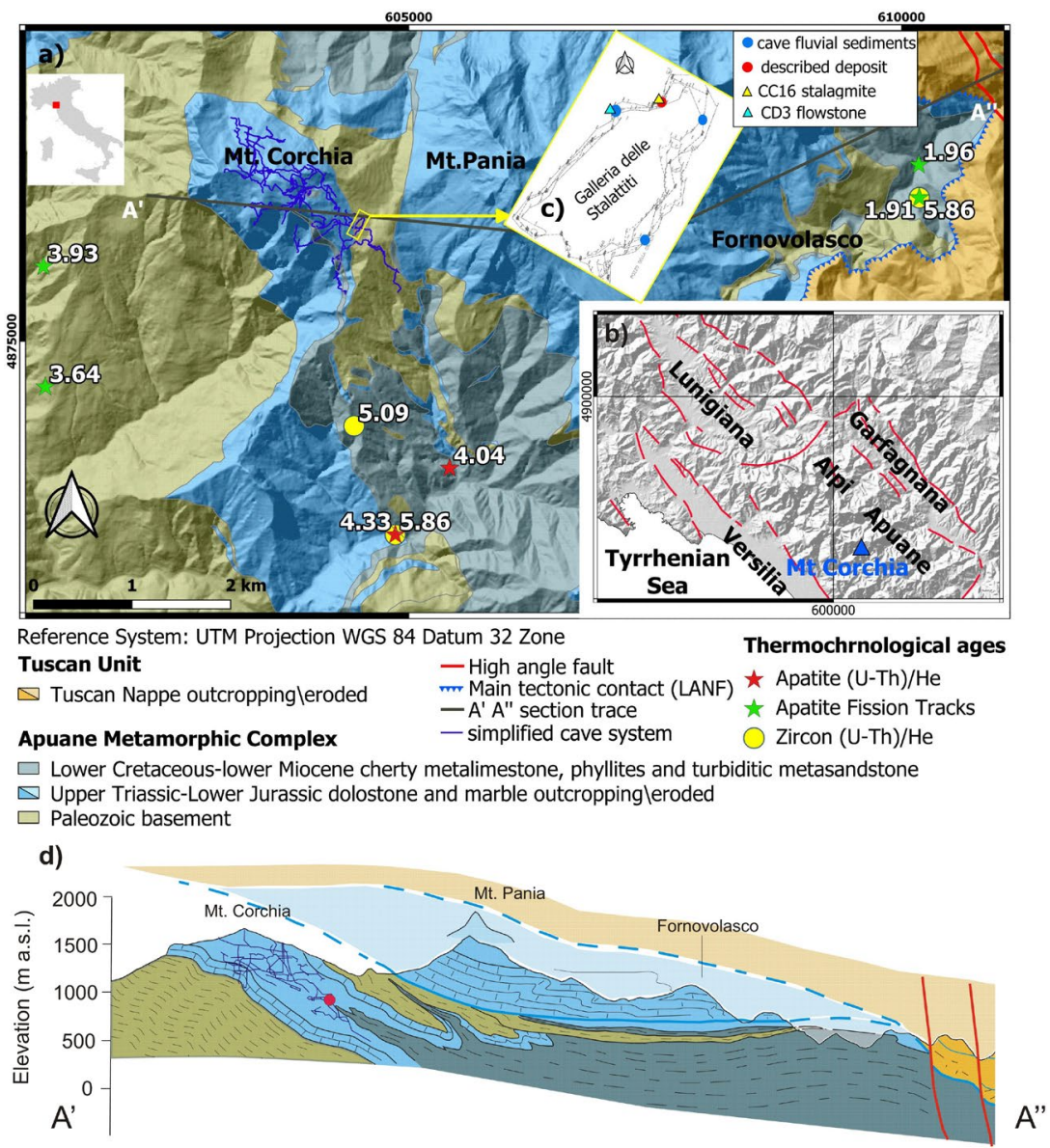

Figure 1. (a) Location and geology of the study area ([39] modified). Red and green stars and yellow circles represent the location of samples used for Apatite (U-Th)/He, apatite fission tracks, and Zircon (U-Th)/He thermochronology ages, respectively [8]. (b) Simplified tectonic sketch of the Garfagnana and Lunigiana valleys. (c) Galleria delle Stalattiti plan map ([40] modified). Circles and triangles show the location of fluvial and calcite deposits, respectively. (d) Geological cross section between $\mathrm{A}^{\prime}$ and $\mathrm{A}^{\prime \prime}$. Dashed and continuous blue lines represent low-angle normal faults (LANFs) (former thrusts reactivated as LANFs: see $[3,41]$ for further tectonic information). The red dot represents the Galleria delle Stalattiti (GdS) location. 
The most complete low-temperature thermochronologic study, based on apatite and zircon fission tracks (AFT, ZFT) combined with apatite and zircon (U-Th)/He ages (AHE, $\mathrm{ZHe}$ ), derived exhumation rates and processes related to the Alpi Apuane tectonic history [8]. The study suggested that the earlier and late Miocene high exhumation rates (up to $>1.4 \mathrm{~mm} /$ year) can be interpreted as related to events of tectonic exhumation, whereas the low exhumation rates $(<0.6 \mathrm{~mm} /$ year $)$ of the last $4 \mathrm{Ma}$ may instead be due to predominantly erosional exhumation.

\subsection{The Corchia Cave System}

The Corchia Cave system, more than $70 \mathrm{~km}$ long and about $1200 \mathrm{~m}$ deep, is mainly carved in the Upper Triassic to Lower Jurassic carbonate core of the Mt. Corchia syncline, confined by the phyllites and metavolcanics (Lower phyllites and Porphyroids, [42]) of the Paleozoic basement. Structural surfaces have guided the cave development, so the system is mainly elongated NW-SE and gently dipping to the SE, parallel to the syncline axial surface [25] (Figure 1). The horizontal passages follow, therefore, the main synmetamorphic litho-structural surfaces of the metacarbonate core (Figure 1b), whereas most of the vertical passages mainly developed along low-displacement high-angle faults and/or fracture systems $[26,43]$. The Mt. Corchia groundwater network is drained mainly by a spring located at $175 \mathrm{~m}$ a.s.l. that flows to the Ligurian Sea via the Vezza River [25,44]. The cave system has 21 entrances at different elevations, the highest opening being close to the top of the mountain (1678 $\mathrm{m}$ a.s.1.) at $1637 \mathrm{~m}$ a.s.l. Most of the horizontal or sub-horizontal phreatic or epiphreatic cave passages are organized in different levels, the major ones of which are at around 1400, 1100-1200, and $900 \mathrm{~m}$ a.s.l., and are connected by steep to vertical passages [26]. This structure suggests different base-level stillstands, allowing the development of three major sub-horizontal levels, interrupted by relatively faster lowering of the base level. Local breakdown/collapse blocks and allochthonous fluvial sediments are the prevalent clastic deposits in the cave.

Our study focuses on the sediments occurring in the GdS, a sub-horizontal passage with floor elevation ranging between 860 and $870 \mathrm{~m}$ a.s.l. and vertically overlain by $\sim 400 \mathrm{~m}$ of rock (mainly phyllites of the Paleozoic basement). It is part of the lower of the three abovementioned sub-horizontal major levels [26]. The gallery is partially filled by chemical (speleothems) and clastic deposits both autochthonous (breakdown/collapse blocks) and allogenic (due to stream transport). The latter are locally exposed along the sidewalls at different heights with different extents and thickness.

\section{Materials and Methods}

To overcome the intrinsic variability of the hypogean environment, we studied the GdS sedimentary section where stratigraphy is clear and continuous ( $\sim 9 \mathrm{~m}$ thick and $\sim 12 \mathrm{~m}$ laterally extended). We collected six samples to study the thin-section grain composition and to infer the possible source area of the allogenic recharge. The fluvial succession was also sampled for paleomagnetism at eight different levels. We sampled the finergrain-size layers by collecting oriented samples for each stratum. At the laboratory, these samples were further reduced to standard cylindric specimens. All the measurements were performed at the Centro Interuniversitario di Magnetismo Naturale (CIMaN-ALP) Laboratory (Peveragno, Cuneo). For each specimen, we measured the natural remanent magnetization (NRM) using an AGICO JR6 spinner magnetometer. The specimens were then step-by-step Alternating Field (AF)-demagnetized by an ASC D-2000 device up to $100 \mathrm{mT}$. Isothermal remanent magnetization (IRM) acquisition and back field were performed on one specimen for each layer.

\section{Results}

\subsection{Clastic Sediment Stratigraphy}

The studied sequence (Figure 2) is mostly composed of clastic material transported and deposited by running water and lithified by calcite cementation. It directly lays on the 
carbonate bedrock and begins with a 1-cm-thick flowstone characterized by a very high detrital content. This is overlain by $0.9 \mathrm{~m}$ of fluvial sediment consisting of alternations of clast-supported conglomerate and medium- to fine-grained calcite-cemented arenite. In several points, the conglomerate layers show clasts imbrication and erosional troughs. The sequence continues with $5 \mathrm{~m}$ of centimetric to decimetric layers of arenite with calcite cement, passing via erosive contact to a 1.5-m-thick, centimetric to decimetric well-rounded heterometric conglomerate. An unconsolidated to partly consolidated $1.5 \mathrm{~m}$ layer of breakdown breccia covers the conglomerate and closes the clastic sequence. It consists of unsorted boulders and cobbles, with a prevalence of rock fall materials, ranging from centimeter- to meter-size clasts and overlain by a few decimeters of unconsolidated carbonate sand draping the irregular surface. A thin calcite flowstone, with several stalagmites grown on it, overlays the succession paraconformibly.

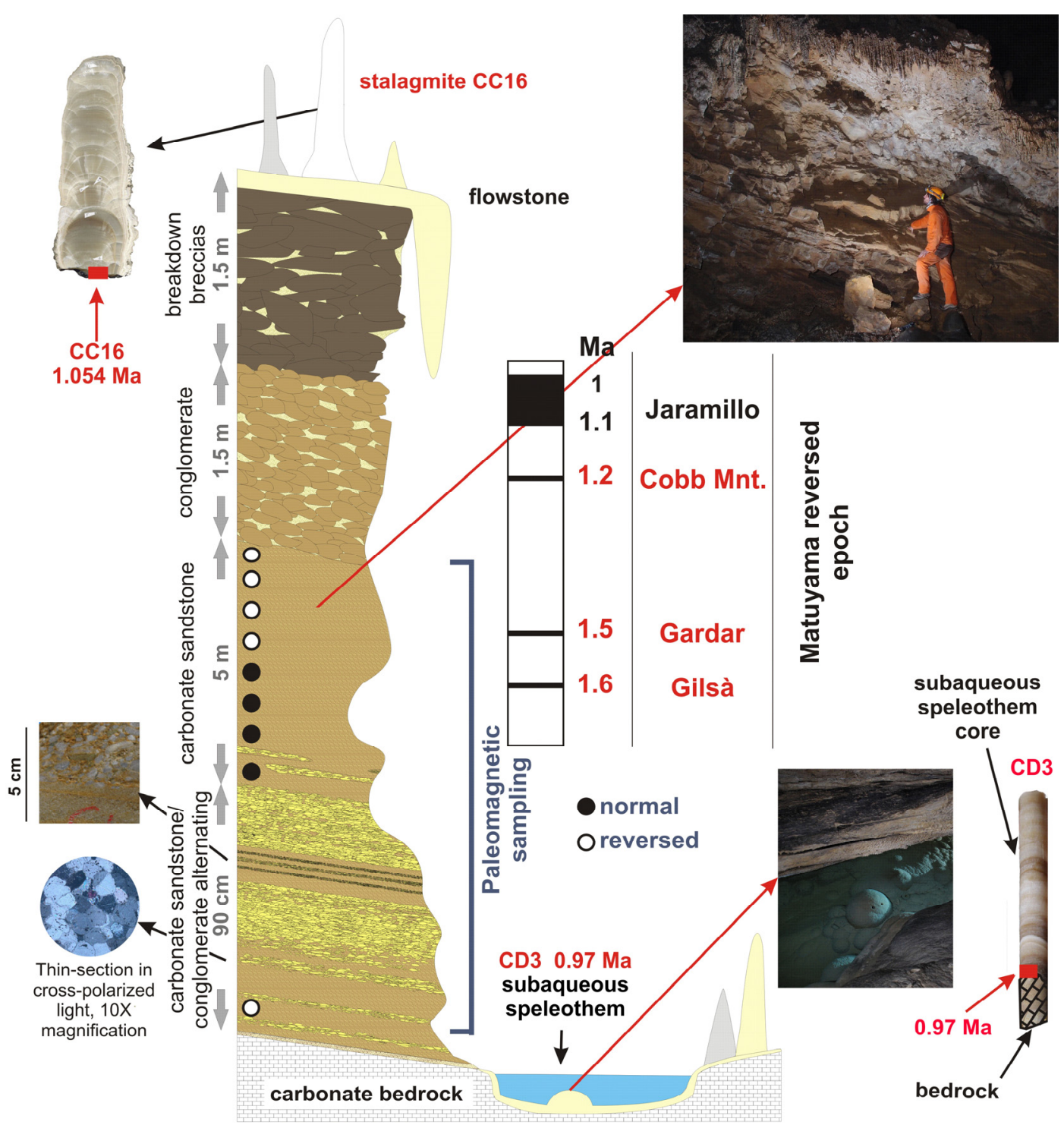

Figure 2. Stratigraphic column of the studied fluvial section and its relationship with speleothems. Vertical axes are not at scale, and the layer thickness is expressed by gray arrows.

At thin-section scale, the conglomerate has a fine carbonate matrix and sub-rounded clasts consisting of mineral grains (calcite, quartz, mica, feldspar, and epidote), sandstone, and metamorphic rocks. Sandstone clasts vary from medium to very fine in size and are well sorted and sub-rounded. They comprise minerals (calcite, quartz, mica, chlorite, feldspar, and oxides) and metamorphic and siliciclastic lithic components. Modal 
analysis carried out on sandstone samples and plotted on a ternary diagram (Figure 3a) following Dickinson [45] show a clustering of samples in the litharenite zone. To better understand the provenance of the detrital grains in the analyzed samples, we plotted them in a Metamorphic-Volcanic-Sedimentary ternary diagram (Figure 3b). Most of the lithics have metamorphic origin, but the presence of lithics of sedimentary origin is not negligible.
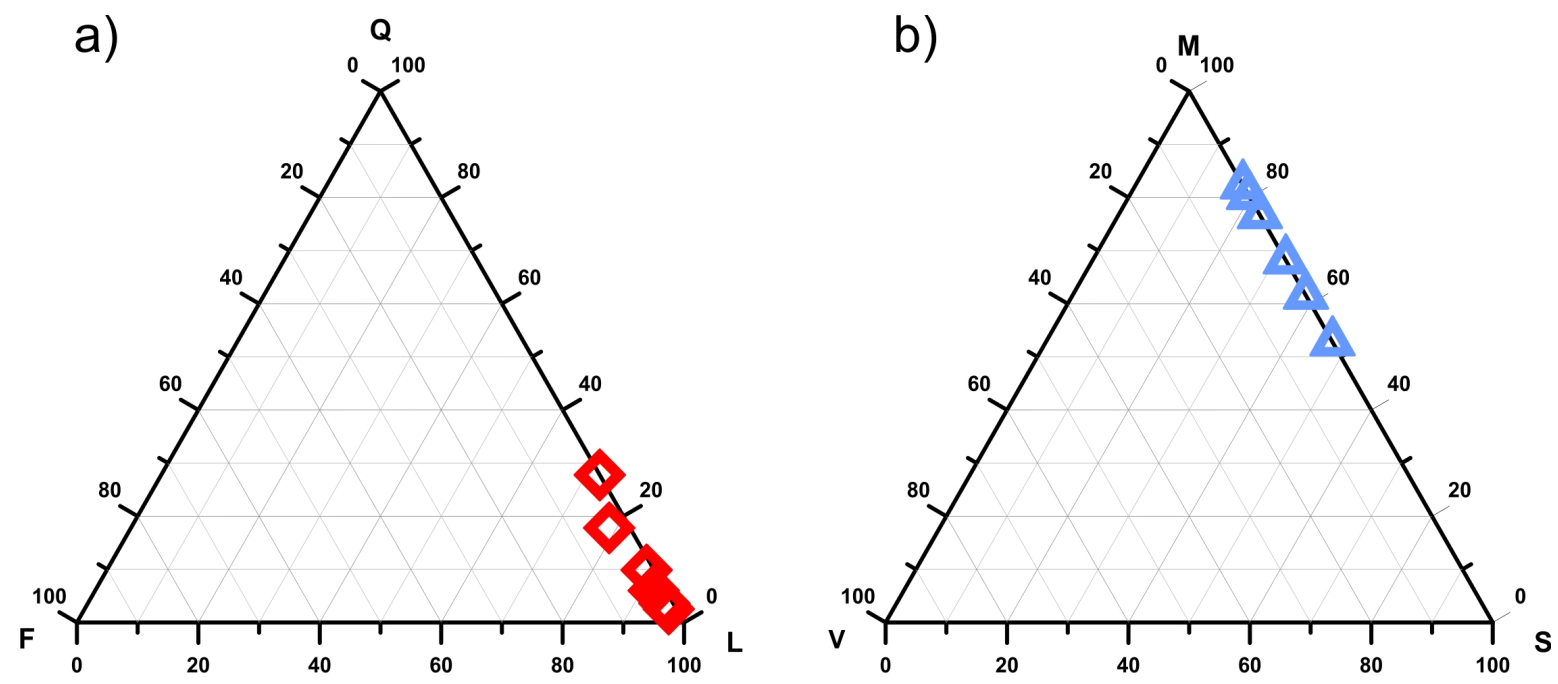

Figure 3. (a) Quartz-Feldspar-Lithic plot summarizing the sample compositions [45]. (b) Ternary diagram MetamorphicVolcanic-Sedimentary of the lithic grains in the analyzed samples: notable is the presence of grains of sedimentary origin.

\subsection{Paleomagnetic Analysis}

Examples of the results of the demagnetization behavior of the specimens are shown in Figure 4a. The isothermal experiments confirm the occurrence of a low-coercivity phase in each layer, saturated by applying 0.3 to $0.5 \mathrm{~T}$ fields. The coercivity is mostly around $20 \mathrm{mT}$. This indicates that the main remanence carrier is magnetite. The intensity of the magnetization is rather low, ranging from $1 \times 10^{-4}$ to $1 \times 10^{-2} \mathrm{Am}^{-1}$, but mostly of ca $3 \times 10^{-3} \mathrm{Am}^{-1}$ (Figure 4b). Zijderveld diagrams [46] reveal the occurrence of two magnetization components, one of low stability, removable by applying a field of 10 to $15 \mathrm{mT}$ and interpreted as a viscous component, and a high-stability component of both normal and reverse polarity, pointing to the origin of the diagram and interpreted as the Characteristic Remanent Magnetization (ChRM) (Figure 4c). The ChRM quality is expressed by the maximum angular deviation (MAD), which mostly ranges from 4.5 to 16. In the layers with low magnetization intensity (of the order of $10^{-4} \mathrm{Am}^{-1}$ ), MADs show higher values of around 20 to 25 . Although these values are large, they have been considered acceptable because in the Zijderveld diagrams it is still possible to recover the magnetic polarity [47]. The mean magnetic polarity was computed using Fisher's Statistics [48]. The normal magnetic polarity is $D=357.2^{\circ}, I=-43.4$, alpha $95=28.2^{\circ}$, Virtual Geomagnetic Pole (VGP) Lat N $71^{\circ}$, Long E $198^{\circ}$; its confidence limit is very high due to both the small number of normal polarity observations $(n=10)$ and the large dispersion of declinations. The mean reverse polarity is $D=186.6, I=-41.7$, alpha95 $=11.6^{\circ}$, VPG Lat $S$ $69^{\circ}$, Long E $173^{\circ}$ (Figure 5). 
a) Specimen $\mathrm{CO} 3-1 \mathrm{C}$



a) Specimen CO4-1A

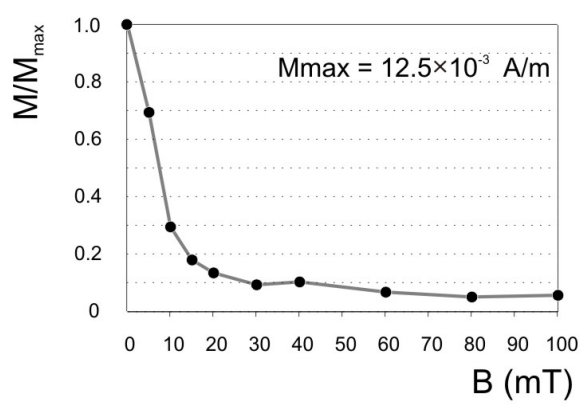

a) Specimen CO8-1B

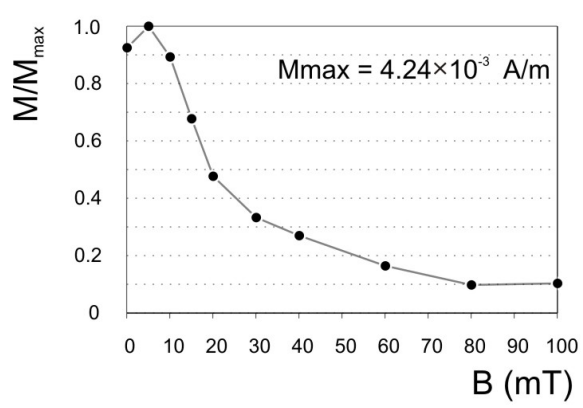

a) Specimen CO8-1C



b)
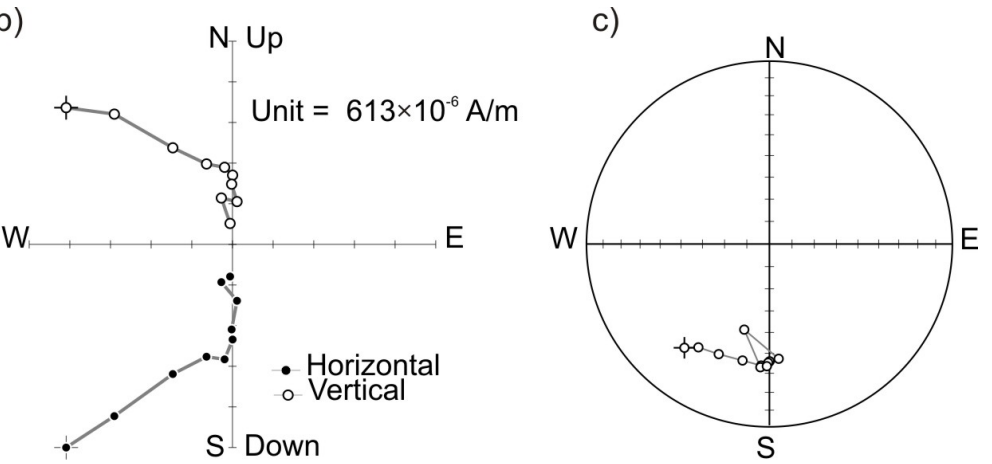

b)


b)
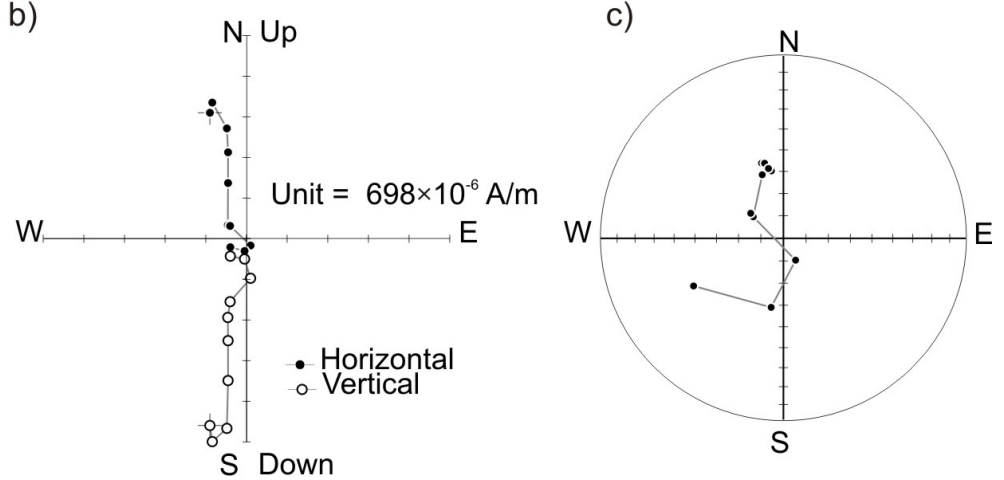

b)

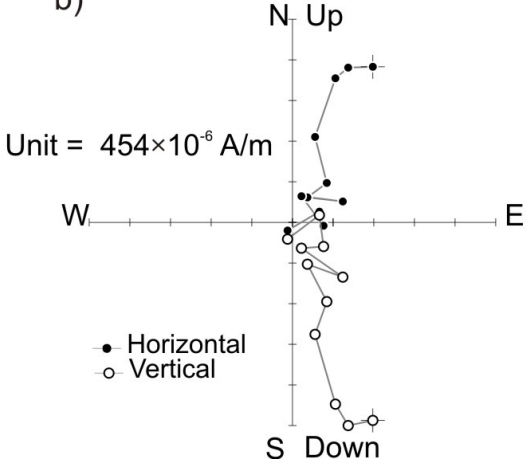

c)

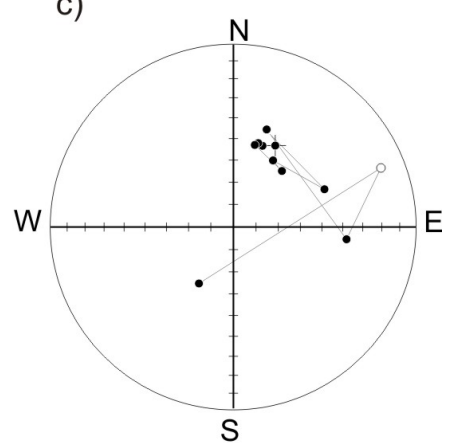

Figure 4. Examples of the magnetization behavior of reversed (first two rows) and normally polarized (last two rows) specimens during Alternating Field (AF) cleaning. For each specimen: (a) the decay of the normalized magnetization intensity versus the applied field; (b) the Zijderveld diagrams (black/white dots are declination/apparent inclination, respectively); and (c) equal-area projection of magnetic direction (black/white dots are positive/negative inclination, respectively). 




Figure 5. Paleomagnetic record. From left to right: polarity succession, latitude of the Virtual Geomagnetic Pole (VGP), magnetic Inclination and declination.

\section{Discussion}

\subsection{Speleothem Ages}

The Corchia Cave and, in particular, the GdS have been the object of wide-ranging paleoclimate research for the past 20 years [49-60]. Tens of speleothems have been dated, with more than 400 very precise radiometric ages $[54,61]$. The calcite of speleothems from the GdS has two important qualities: it is exceptionally free from detrital components, and it is rich in uranium content. In its deepest part, the GdS is overlain by about $400 \mathrm{~m}$ of rock, so the seepage water responsible for speleothem formation has lost most of its detrital load, leading to the precipitation of exceptionally pure calcite. The Brecce di Seravezza formation probably is the main source of the relatively high uranium content that allows very precise radiometric dating using both conventional U-series and the more novel U-Pb techniques $[62,63]$. Among the hundreds of ages obtained until now, the oldest comes from CC16, one of the stalagmites topping the described succession. The bottom of the stalagmite has been dated by Woodhead et al. [63] at $1.054 \mathrm{Ma}(2 \sigma=0.024)$ using a methodology that allows producing $\mathrm{U}-\mathrm{Pb}$ ages of high quality. Moreover, in the lower section of this gallery, a small and shallow lake, with walls covered by calcite flowstones, 
is present. On the floor, the $\mathrm{CaCO}_{3}$ deposition has formed a subaqueous drapery with a cave-cloud shape, with lily-pad structures created where calcite crystals grow radially from projecting substrata. U-Pb dating shows that the basal age of the subaqueous calcite deposit reaches $0.967+0.018 /-0.006 \mathrm{Ma}$ [59].

\subsection{The Galleria Delle Stalattiti (GdS) Evolution}

Reconstructing the evolution of the GdS requires considering some uncertainties. A chronological interpretation of cave sedimentation is often complex. Waterways can be continuously obstructed and reopened, the sedimentation rate can be extremely variable, and deposits can be diachronous.

According to our stratigraphic and chronological reconstruction, the GdS was firstly formed as a phreatic tube, whose original morphology is preserved in the ceiling shape. Successively, the tube was affected by downcutting in epiphreatic to vadose conditions. Deposition is probably related to the transition from phreatic to vadose conditions and to a phase with high-solid-load transport. The grain sizes of the fluvial deposits and the occurrence of erosional surfaces testify to changes in water energy that could have also a climatic meaning. Otherwise, the fluvial deposits facies testify to a transition from lowto high-energy sediments (sand to pebble and gravel) progressively filling the passages. An increase of energy in the stream regime is also marked by the upper erosional surface of carbonate arenite, followed by coarse conglomerate deposition. A subsequent depositional phase, which was concurrent with widespread roof breakdown, was followed by an erosional phase cutting the entire sequence. A phase of calcite precipitation topped the detrital succession with a thin flowstone and stalagmites at least since $1.05 \pm 0.2 \mathrm{Ma}$ [63]. After the erosive phase ended, a small lake formed at the bottom of the gallery, where subaqueous speleothems have been growing directly on the rock substratum since $\sim 0.97 \mathrm{Ma}$ [59], indicating the definitive interruption of vadose flow.

The age of the carbonate arenite in the GdS can be constrained by coupling paleomagnetic data from fluvial deposits and radiometric ages from speleothems. At the base of the deposits, the magnetic zones (Figures 2 and 5) start with a reversed polarity record (older deposition phase: layer 9) followed by a normal polarity record (layers 8 to 5 ) and then by a reverse polarity record at the top (younger deposition phase: layers 4 to 1 ). Stalagmite CC16 caps the stratigraphic succession, providing an age of $1.05 \mathrm{Ma}$ [63]. This means that the fluvial deposition reasonably started within the Matuyama Chron before the Jaramillo subchron (1071-991 ka), [64]. During the Matuyama, several short geomagnetic reversal events have been documented (see [64] and reference therein for details). Many of these are still controversial because defining the occurrence of a short reversal requires a high-precision reconstruction of a paleomagnetic field, which is dependent upon the temporal resolution of the archives and the geological constraints. Besides, not all the reported reversals have been recorded at all studied sites (see [65] for details). For these reasons, we have considered only the events reported by Simon et al. [64]. These have been detected by the relative paleo-intensity (geomagnetic dipole moment low) and Be-ratio records, and are commonly reported in the literature $[65,66]$. We identified three different events/subchrons that could match the normal polarity record from layers 8 to 5 in the cave sediment, namely the Cobb Mountains (1176/1204 $\pm 5 \mathrm{ka})$, the Gandar (1459 $\pm 9 \mathrm{ka})$, and the Gilsa ( $1587 \pm 8 \mathrm{ka})$. This means that the fluvial deposition started at least before the normal Cobb Mountains subchron zone in the Matuyama reverse epoch, dated at about 1.2 Ma [64]. A local base-level fall may have occurred during the following reverse subchron prior to $1.05 \mathrm{Ma}$, causing the incision phase that cut the sediments underlying the CC16 stalagmite; this erosion phase had already expired at $\sim 0.97 \mathrm{Ma}$ when the lake had formed, and the calcite deposition took place. Since $\sim 1 \mathrm{Ma}$, the scenario probably remained unchanged, as testified by the continuous and undisturbed deposition of the subaqueous speleothem [59]. The time lapse occurred between the end of the clastic deposition and the beginning of $\mathrm{CC} 16$ formation is unknown: the most conservative hypothesis is to consider this interval negligible. 
The clastic deposition within the GdS probably occurred when this horizontal passage was close to the local base level. Furthermore, the erosion of coarse fluvial deposits requires a hydraulic gradient, therefore implying that the GdS was above local, and even more above the global base level, before speleothem formation, but its past real elevation is unknown. Presently, the base level of this karst system is at $175 \mathrm{~m}$ a.s.l., in the Vezza River valley, close to the contact between the Paleozoic basement and dolostone, that is, $\sim 700 \mathrm{~m}$ below the present GdS elevation. The presence in the Corchia Cave system of relict phreatic passages at $\sim 1600 \mathrm{~m}$ a.s.1. [67], that is, $\sim 700 \mathrm{~m}$ above the GdS, implies that during GdS formation, there were at least 700-m-thick previously exhumed rocks. In summary, radiometric and paleomagnetic data indicate that at least by the Early Pleistocene (1.6-1.2 Ma), fluvial sediments were deposited in the GdS, indicating that this portion of Mt. Corchia was necessarily above the sea level at that time.

\subsection{Exhumation/Uplift History from Thermochronological Dating for the Alpi Apuane}

Since the first application of thermochronologic methods in the Alpi Apuane [68], various authors have tried to derive exhumation and rock-uplift rates from them [4-8]. Most of these authors agree on an exhumation rate ranging from 1.3 to $1.8 \mathrm{~mm} /$ year between about 6 and $4 \mathrm{Ma}$ (late Miocene-early Pliocene), followed by a lower rate ranging from 0.6 to $0.9 \mathrm{~mm} /$ year, since early Pliocene to the present (Table 1).

Table 1. Summary of the Alpi Apuane exhumation rate estimated in previous studies.

\begin{tabular}{cccc}
\hline Ages & Exhumation Rate mm/Year & Method & Reference \\
\hline 6-4 Ma & 1.4 & & {$[8]$} \\
$4-0 \mathrm{Ma}$ & 0.6 & AFT, ZFT, AHe, ZHe & {$[8]$} \\
6-4 Ma & $1.3-1.8$ & AFT & {$[7]$} \\
4-0 Ma & $0.6-0.9$ & AFT & {$[7]$} \\
middle Pliocene & 0.8 & AFT, AHe, ZHe & {$[6]$} \\
6-2 Ma & $0.8-1.7$ & AFT, ZFT & {$[5]$} \\
\hline
\end{tabular}

AFT: Apatite Fission Tracks; ZFT: Zircon Fission Tracks; AHE: Apatite (U-Th)/He; ZHe: Zircon (U-Th)/He. The ages represent the time periods relevant to the exhumation rate estimates.

Fellin et al. [8] suggested a high exhumation rate $(>1.4 \mathrm{~mm} /$ year $)$ during the late Miocene, followed by a decrease to $\leq 0.6 \mathrm{~mm} /$ year in the Pliocene. The only inconsistency with this interpretation, as noted by the authors, is related to some samples of a small region in the easternmost Alpi Apuane (i.e., Fornovolasco area, $7 \mathrm{~km}$ east of our studied site; see Figure 1) where AFT ages as young as 1.9 Ma were obtained [5]. Close to Mt. Corchia, AFT ages of around 3.8 Ma are reported [8]. The difference in age between the data at Fornovolasco and the data west of Mt. Corchia could either indicate a real differential exhumation or it could relate to overscatter of the data. As clearly shown in Figure 1a,d (see also $[2,31,69,70])$, no first-order high-angle faults with a high displacement throw (hundreds to thousands of meters) occurs just east of Mt. Corchia, justifying a significant differential uplift. No splitting of the metamorphic core in two sub-domains-Mt. Corchia in the west and Fornovolasco in the east-is also feasible, and therefore a differential exhumation history between them may be ruled out.

Notably, the highest of the three horizontal/sub-horizontal levels of the Corchia Cave system, about $500 \mathrm{~m}$ above the GdS, hosted the CC17-f2 stalagmite dated by Engel et al. [71] about 1.9 Ma. This age testifies a Corchia karst system well developed, at least in its higher part, with galleries already formed and speleothems growing. This scenario is inconsistent with AFT ages of about $1.9 \mathrm{Ma}$, indicating a depth of at least $3000 \mathrm{~m}$ just a few kilometers far. On this basis, we exclude the AFT ages from Fornovolasco and we consider only the AFT ages derived from the nearby Paleozoic rocks $[5,8]$, west of the Corchia Cave, as representative of the whole Mt. Corchia area and of the eastern side of the Alpi Apuane core. 


\subsection{Rock Uplift Rates from Cave Evolution and Hypogean Deposits}

Rock uplift rates can be inferred from exhumation rates, assuming that uplift triggers a similar denudation rate at regional scale. Otherwise, cave system evolution can furnish a reliable indication of the lowering rate of the local base level, which is usually strictly dependent on river incision. So, also in this different approach, we must presume that river incision acts as a quick-response process to tectonic uplift. These assumptions are quite acceptable in mountain regions, where surface processes are very active and the erosion rate is usually higher than uplift rate. Despite this intrinsic uncertainness of the two approaches, a rough estimate of uplift rates can provide useful information to reconstruct the tectonic dynamics of a mountain range.

We use the new chronological data for the GdS combined with the available thermochronology data to provide revised estimates of the uplift rates of this sector of the Alpi Apuane since the late Pliocene. The approximations previously discussed imply that the rates we are going to propose could underestimate the true uplift rate. For all these reasons, hereafter, we refer to the uplift rate computed between the closure of the apatite geothermal system and the deposition of CC16 as a minimum uplift rate. We take as major local constraints (i) the U-Pb speleothems ages; (ii) the magnetostratigraphic chronologies considering the three possible normal subchrons older than $1 \mathrm{Ma}$ (Cobb Mountain, Gardar, Gilsa; Table 2); and (iii) the gallery morphology and the reconstruction of the cave infill phases (see Table 2).

Table 2. Ages used to estimate the uplift rates.

\begin{tabular}{|c|c|c|c|c|c|c|}
\hline Sample & Present Elevation ( $\mathrm{m}$ a.s.1.) & Age (Ma) & $2 \sigma$ & Dating Method & Lithology Formation Unit & Reference \\
\hline CD3 & 870 & 0.97 & 0.010 & $\mathrm{U}-\mathrm{Pb}$ & Subaqueous flowstone & [59] \\
\hline CC16 & 875 & 1.05 & 0.024 & U-Pb & Stalagmite & [63] \\
\hline $\mathrm{CO} 5-8$ & $865-874$ & $1.176 / 1.204$ & 0.005 & $\begin{array}{l}\text { Paleomagnetic chronology } \\
\text { Cobb Mountain }\end{array}$ & Hypogean deposit & This work (using [64]) \\
\hline $\mathrm{CO} 5-8$ & $865-874$ & 1.459 & 0.009 & $\begin{array}{c}\text { Paleomagnetic chronology } \\
\text { Gardar }\end{array}$ & Hypogean deposit & This work (using [64]) \\
\hline $\mathrm{CO} 5-8$ & $865-874$ & 1.587 & 0.005 & $\begin{array}{c}\text { Paleomagnetic chronology } \\
\text { Gilsa }\end{array}$ & Hypogean deposit & This work (using [64]) \\
\hline $\mathrm{CP} 1$ & 675 & 3.93 & 0.36 & AFT & Phyllite Paleozoic basement & [5] \\
\hline CP3(4) & 650 & 3.64 & 0.71 & AFT & Phyllite Paleozoic basement & [5] \\
\hline
\end{tabular}

Considering the ages of the GdS deposits, the minimum local base level allowing gallery formation and fluvial sediment infilling, and the AFT closure depths (i.e., the depth of the $110^{\circ} \mathrm{C}$ isotherm), a minimum rock uplift rate can be inferred from late Pliocene to Early Pleistocene.

To obtain a more reliable estimate, we must consider that at the time of GdS filling deposition, the rock where samples for AFT analysis are located were still buried below a thickness of rock successively eroded (Figure 6). In the simplest hypothesis that valley slopes have maintained a constant profile, this thickness should be of the same order of the valley incision and so of the base-level lowering, that is, $\sim 700 \mathrm{~m}$. Considering that the most elevated sections of the Alpi Apuane ridge consists of carbonate formations, we can suppose a slower denudation rate for summit areas and consequently a progressive increasing of slope gradient due to river incision. In this more realistic framework, the residual burial over AFT-dated rock samples at GdS deposition time would be around $500 \mathrm{~m}$ (see Figure 6). In other words, exhumation/uplift rates from the time of AFT closure to GDS sediment formation must be calculated on a thickness that is roughly $500 \mathrm{~m}$ lower than that calculated based only on geothermal gradients. 




Figure 6. Schematic representation of the geomorphic evolution of Mt. Corchia in the last 1.2-1.6 Ma, considering the hypothesis that valleys were affected by an erosion rate higher than carbonate ridges.

We have estimated the exhumation/uplift rates considering two different geothermal gradients, $25^{\circ} \mathrm{C} / \mathrm{km}$ and $30^{\circ} \mathrm{C} / \mathrm{km}$, and three hypothetical ages for basal GdS sediments, $\sim 1.2, \sim 1.5$, and $\sim 1.6 \mathrm{Ma}$, obtaining rates ranging from $\sim 1.6$ to $\sim 1.1 \mathrm{~mm} /$ year (Table 3 ).

Table 3. Rock uplift rates of Mt. Corchia constrained by AFTs (from [5]) and the magnetostratigraphic dating.

\begin{tabular}{|c|c|c|c|c|c|}
\hline \multicolumn{4}{|c|}{ Minimum Rock Uplift Rate from Closure AFT to GdS Clastic Deposition } & \multicolumn{2}{|c|}{$\begin{array}{l}\text { Maximum Rock Uplift Rate from GdS } \\
\text { Clastic Deposition to Present }\end{array}$} \\
\hline Subchrone & Age (Ma) & $\begin{array}{c}\text { Geothermal Gradient } 25^{\circ} \mathrm{C} / \mathrm{km} \\
\text { (mm/year) }\end{array}$ & $\begin{array}{c}\text { Geothermal Gradient } 30{ }^{\circ} \mathrm{C} / \mathrm{km} \\
\text { (mm/year) }\end{array}$ & Subchrone & (mm/year) \\
\hline Cobb Mountain & 1.2 & 1.3 & 1.1 & COBB MNT & 0.6 \\
\hline Gardar & 1.5 & 1.5 & 1.2 & GARDAR & 0.5 \\
\hline Gilsa & 1.6 & 1.6 & 1.3 & GILSA & 0.4 \\
\hline
\end{tabular}

The phase of clastic deposition in the GdS was followed by a relative lowering of the local base level, which was responsible for an erosive phase cutting throughout the entire fluvial deposits until the carbonate bedrock. The migration of the cave stream toward lower passages allowed the formation of the Laghetto basso, a small pool mostly fed by dripping, where subaqueous speleothems have been continuously growing during about the last million years. This suggests that during this time, the uplift of the area was uniform, with no significant changes that could have disturbed or interrupted the seepage patterns and the lake feeding.

Moreover, assuming that a minimum hydraulic gradient was present during cave filling and considering the modern elevation of the sampling site at ca. $870 \mathrm{~m}$ a.s.l., the maximum uplift rate in the last 1.2-1.6 Ma in the Corchia area is estimated around $0.4 / 0.6 \mathrm{~mm} /$ year (Table 3). These values agree with the Middle-Late Pleistocene incision rates estimated by Piccini et al. [20] in the nearby Frigido River basin and with the vertical component of motion derived for the area by Bennett et al. [72] using the Common-mode 
Signal Reduced time series of GPS networks and consistent with an uplift mainly driven by erosion.

\subsection{Sediment Sources}

Petrographic analysis and lithic components of the sampled fluvial deposits furnish information about the sediment sources. The presence of Paleozoic basement and marble clasts, as well as of other minerals typical of the Corchia area, indicates that at least a part of the source rocks would have been in a catchment area very close to the deposition site. Notably, non-metamorphic sandstones are also present as lithic components (Figure 3a,b), despite the absence of such rocks in the areas surrounding Mt. Corchia at the present time (Figure 1a,d). Alluvial infilling with pebbles of non-metamorphic rocks was already described by Piccini $[26,67,73]$ in the higher levels of the Corchia system and dubitatively attributed to remnants of Ligurian Units in the catchment area during their deposition. Looking at the regional geology, non-metamorphic sandstones are present in the Tuscan Unit and the Ligurian Units or as secondary sediments in Neogene deposits. Presently, the closest outcrops of these units are several kilometers far from the Corchia Cave and at lower elevations than the upper entrances of the karst system. Consequently, the source of the studied deposits had to be completely removed (see Figure 1a,d) during the erosion-mediated exhumation of the metamorphic units activated by high-angle normal faulting that started in the region $4-5 \mathrm{Ma}$ (e.g., [8,37]). We can so suppose that the allogenic components of sediment deposed in the GdS derive from the erosion of these materials deposed in the higher levels of the karst system during a previous deposition phase.

A schematic reconstruction of the Corchia Cave system and its catchment area development, from 2.5 Ma to the present, is proposed in Figure 7. AFT constrain the Apuane Metamorphic Complex, as covered by the Tuscan and Ligurian Units already juxtaposed by low-angle normal faults (LANFs) [3,41] still at a depth of $3.5-2.8 \mathrm{~km}$ (with a $25^{\circ} \mathrm{C}$ or $30{ }^{\circ} \mathrm{C}$ geothermal gradient, respectively) at about 3.8 Ma. The Apuane metamorphic core, including the zone hosting the Corchia Cave system, rose from depth to surface with at least three significant stillstand phases, as testified by the three major horizontal/sub-horizontal levels of galleries at around 1400, 1200-1100, and $900 \mathrm{~m}$ above the present sea level [26], the higher of which was carved, and partially filled by alluvial sediments of non-metamorphic carbonate sandstone [26], before 1.9 Ma [71]. This testifies that before that time, surface waters were drained through the Corchia system coming from a catchment area partially formed by the Tuscan and Ligurian Units overlaying the metamorphic ones. This presently eroded shallow crustal section fed the cave fluvial deposits. The lowest of the main levels, where the GdS is found, was carved at least before $1.6-1.2 \mathrm{Ma}$, when the deposition of the alluvial sediments occurred. Afterward, the base-level lowering led to stream erosion of the hypogean infill until the basal bedrock. The development of the small lake with submerged speleothems growing continuously since $\sim 1.0$ Ma testifies to the stability of this cave sector and possibly a continuous, uniform uplift in the area. 

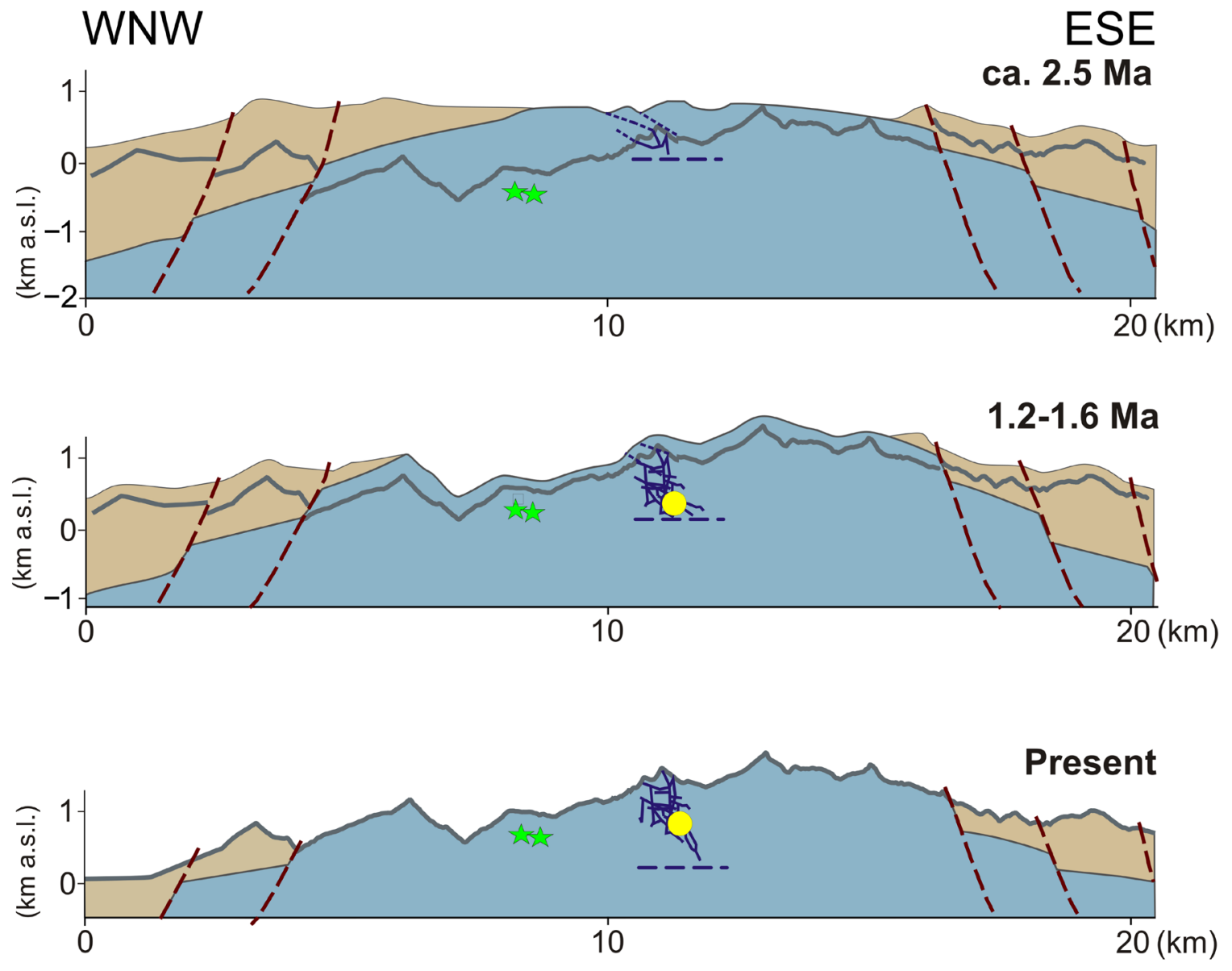

\section{Tuscan and Ligurian Units ! High angle fault Simplified Corchia system Apuane Metamorphic Complex \\ Main tectonic contact \\ AFT sampling site \\ $\cdots$ Supposed passage \\ Base level}

Figure 7. Schematic model showing the proposed chronology of the Corchia Cave system evolution and Alpi Apuane uplift over the last 2.5 Ma based on hypogean radiometric and paleomagnetic analyses and AFT thermochronology from the literature (Figure 1 and Table 2). 2.5 Ma: the highest of the sub-horizontal passages of the Corchia Cave system were already carved, while epigean streams sank and fed the sedimentary deposits with material eroded from metamorphic and non-metamorphic units. The AFT data locations are still buried at about 1.5 km depth. 1.2-1.6 Ma: the two higher karst levels of the Corchia Cave were completely developed, the lowest one was already carved near the base level, and the clastic infilling was occurring in the GdS. Present: the GdS is at about $870 \mathrm{~m}$ a.s.l., and a new phreatic level is forming around the modern base level.

\section{Conclusions}

Using robust dating from independent hypogean deposits in the Corchia Cave, we provide new information about the tectonic uplift of the Alpi Apuane since the lower Pliocene to the present. In particular, the evolution of the GdS is reconstructed by combining morphology observations, radiometric ages from speleothems, and magnetostratigraphic records from fluvial hypogean deposits (Figure 7). The ages suggest the GdS was carved as a phreatic tube and successively filled by fluvial deposits before the beginning of one of the normal subchrons comprised within the Matuyana reverse epoch, that is, about $\sim 1.6 / 1.2 \mathrm{Ma}$ ago. Between 1.6/1.2 and 1.0 Ma, a strong erosive fluvial phase testified for a local base-level lowering. This phase ended before 1.0 Ma, when the continuous and undis- 
turbed deposition of subaqueous speleothems began. Based on these data, we estimate a minimum rock uplift rate of the Alpi Apuane since the late Pliocene to Early Pleistocene $\left(1.6 / 1.2 \mathrm{Ma}\right.$ ) of $\sim 1.6 / 1.3$ and 1.3/1.1 mm/year (for 25 and $30^{\circ} \mathrm{C} / \mathrm{km}$ geothermal gradient values, respectively). This phase was followed by a decrease to $\sim 0.4 / 0.6 \mathrm{~mm} /$ year, in good agreement with the modern vertical velocity estimated by Bennett et al. [72] from continuous GPS station analysis ( $0.5 \mathrm{~mm}$ /year) and congruent with rock uplift driven mainly by erosion. The overall tectonic implications of these new estimated exhumation rates and rock uplift are outside the scope of this paper. Nevertheless, we would like to highlight the relevance of tectonics and of a high exhumation rate until the Early Pleistocene (not the Pliocene, as previously assumed) with a decreasing rate since at least 1 Ma. Further works, considering in a regional perspective thermochronologic ages and other constrains as hypogean deposits or stable oxygen isotope paleoaltimetry (e.g., [73]), will allow a better understanding of the vertical movements that affected the Apennine chain.

The petrographic study of the fluvial sediments highlights the presence of lithic components sourced from rocks no longer present in the modern Corchia catchment area. This implies an inversion of relief probably occurred during the Early Pleistocene, suggesting that the Corchia allogenic catchment area was a valley floor draining material from a cover since eroded. During an erosion-mediated exhumation history, probably activated by high-angle normal faulting, the carbonate valley floor became a ridge, as is the case in the present landscape. Further investigations in the higher cave levels could improve time constraints, allowing a more detailed reconstruction of tectonic uplift versus stillstand phases during the Pliocene-Early Pleistocene. Our results thus highlight the importance of several independent proxies for estimating exhumation or rock uplift rates in orogenic settings, because this process, even over time spans of less than $5 \mathrm{Myr}$, is not steady state. A comprehensive study of hypogean sediments in old karst terrains, coupled with dating, could therefore provide helpful tools to better understand and constrain the exhumation history of recent and active mountain belts.

Author Contributions: Conceptualization, I.I., F.M. (Francesco Mazzarini), G.M., G.Z., and R.D.; investigation, I.I., F.M. (Francesco Mazzarini), E.Z., J.H., J.W., A.R., F.M. (Flavio Milazzo), and D.P.; writing-original draft, I.I., F.M. (Francesco Mazzarini), G.M., L.P., E.Z., G.Z., and R.D.; and writingreview and editing, I.I., F.M. (Francesco Mazzarini), G.M., L.P., E.Z., G.Z., R.D., D.P., and E.R. All authors have read and agreed to the published version of the manuscript.

Funding: The speleothem research performed in this study was funded by the Australian Research Grants DP110102185 (to RND, JDW, and GZ) and DP0664621 (to JDW).

Institutional Review Board Statement: Not applicable.

Informed Consent Statement: Not applicable.

Data Availability Statement: Not applicable.

Acknowledgments: We are grateful to Federico Andreetto and Claudio Robustelli for their collaboration in paleomagnetic analysis, to the Parco Regionale delle Alpi Apuane for allowing the sampling in the Corchia Cave, to the Coop. Sviluppo e Futuro Levigliani for allowing us free admission to the touristic path, and to the Federazione Speleologica Toscana for speleological support. We are grateful to the reviewers for their comments and suggestions, which helped in improving and clarifying the text.

Conflicts of Interest: The authors declare no conflict of interest. The funders had no role in the design of the study; in the collection, analyses, or interpretation of data; in the writing of the manuscript; or in the decision to publish the results.

\section{References}

1. Carmignani, L.; Kligfield, R. Crustal extension in the northern Apennines: The transition from compression to extension in the Apuan Alps core complex. Tectonics 1990, 9, 1275-1303. [CrossRef]

2. Carmignani, L.; Decandia, F.A.; Fantozzi, P.L.; Lazzarotto, A.; Liotta, D.; Meccheri, M. Tertiary extensional tectonics in Tuscany (northern Apennines, Italy). Tectonophysics 1994, 238, 295-315. [CrossRef] 
3. Molli, G.; Carlini, M.; Vescovi, P.; Artoni, A.; Balsamo, F.; Camurri, F. Neogene 3-D structural architecture of the north-west Apennines: The role of the low-angle normal faults and basement thrusts. Tectonics 2018, 37, 2165-2196. [CrossRef]

4. Coli, M. Time and mode of uplift of the Apuane Alps metamorphic complex. Atti Tic. Sci. Terra 1989, 32, 47-56.

5. Abbate, E.; Balestrieri, M.L.; Bigazzi, G.; Norelli, P.; Quercioli, C. Fission-track datings and recent rapid denudation in northern Apennines, Italy. Mem. Soc. Geol. Ital. 1994, 48, 579-585.

6. Brandon, M.; Abbate, E.; Balestrieri, M.L.; Bernet, M.; Bigazzi, G.; Picotti, V.; Reiners, P.; Zattin, M.; Zuffa, G.G. Quantifying Exhumation History across the Northern Apennines; Washington EOS Transactions American Geophysical Union: San Francisco, CA, USA; Volume 82.

7. Balestrieri, M.L.; Bernet, M.; Brandon, M.T.; Picotti, V.; Reiners, P.; Zattin, M. Pliocene and Pleistocene exhumation and uplift of two key areas of the Northern Apennines. Quat. Int. 2003, 101, 67-73. [CrossRef]

8. Fellin, M.L.; Reiner, P.W.; Brandon, M.T.; Wütrich, E.; Balestrieri, M.L.; Molli, G. Thermochronologic evidence for the exhumational history of the Apuan Alps metamorphic core complex, northern Apennines, Italy. Tectonics 2007, 26. [CrossRef]

9. Berger, G.W.; York, D. Geothermometry from dating experiments. Geochim. Cosmochim. Acta 1981, 45, 795-811. [CrossRef]

10. Ford, D.; Williams, P.D. Karst Hydrogeology and Geomorphology; Wiley: Chichester, UK, 2007; p. 562.

11. Granger, D.E.; Fabel, D.; Palmer, A.N. Pliocene-Pleistocene incision of the Green River, Kentucky, determined from radioactive decay of cosmogenic 26Al and 10Be in Mammoth Cave sediments. Geol. Soc. Am. Bull. 2001, 113, 825-836. [CrossRef]

12. Häuselmann, P.; Granger, D.E.; Jeannin, P.Y.; Lauritzen, S.E. Abrupt glacial valley incision at 0.8 Ma dated from cave deposits in Switzerland. Geology 2007, 35, 143-146. [CrossRef]

13. Strasser, M.; Strasser, A.; Pelz, K.; Seyfried, H. A mid Miocene to early Pleistocene multi-level cave as a gauge for tectonic uplift of the Swabian Alb (Southwest Germany). Geomorphology 2009, 106, 130-141. [CrossRef]

14. Calvet, M.; Gunnell, Y.; Braucher, R.; Hez, G.; Bourles, D.; Guillou, V.; Delmas, M.; ASTER Team. Cave levels as proxies for measuring post-orogenic uplift: Evidence from cosmogenic dating of alluvium-filled caves in the French Pyrenees. Geomorphology 2015, 246, 617-633. [CrossRef]

15. Springer, G.S. Clastic sediments in caves. In Encyclopedia of Caves; Culver, D., White, W., Eds.; Elsevier: Cambridge, MA, USA, 2005; pp. 102-108.

16. Martini, I. Cave clastic sediments and implications for speleogenesis: New insights from the Mugnano Cave (Montagnola Senese, Northern Apennines, Italy). Geomorphology 2011, 134, 452-460. [CrossRef]

17. Bögli, A. Karst Hydrology and Physical Speleology; Springer: Berlin, Germany, 1980.

18. Palmer, A.N. Cave levels and their interpretation. Bul. Natl. Speleol. Soc. Am. 1987, 49, 50-66.

19. Farrant, A.R.; Smart, P.L.; Whitaker, F.F.; Tarling, D.H. Long-term Quaternary uplift rates inferred from limestone caves in Sarawak, Malaysia. Geology 1995, 23, 357-360. [CrossRef]

20. Piccini, L.; Drysdale, R.; Heijnis, H. Karst morphology and cave sediments as indicators of the uplift history in the Alpi Apuane (Tuscany, Italy). Quat. Int. 2003, 101, 219-227. [CrossRef]

21. Richards, D.A.; Dorale, J.A. Uranium-series chronology and environmental applications of speleothems. Rev. Mineral. Geochem. 2003, 52, 407-460. [CrossRef]

22. Ballesteros, D.; Giralt, S.; García-Sansegundo, J.; Jiménez-Sánchez, M. Quaternary regional evolution based on karst cave geomorphology in Picos de Europa (Atlantic Margin of the Iberian Peninsula). Geomorphology 2019, 336, 133-151. [CrossRef]

23. Rapetti, F.; Vittorini, S. Carta Climatica Della Toscana Centro-Settentrionale; Pacini Editore: Pisa, Italy, 1994.

24. Catasto on Line Delle Grotte Della Regione Toscana 2009. Federazione Speleologica Toscana. Available online: http:/ / speleotoscana. it/programmi_php/catasto/menu.php (accessed on 14 May 2020).

25. Piccini, L.; Zanchetta, G.; Drysdale, R.N.; Hellstrom, J.; Isola, I.; Fallick, A.E.; Leone, G.; Doveri, M.; Mussi, M.; Mantelli, F.; et al. The environmental features of the Monte Corchia cave system (Apuan Alps, Central Italy). Int. J. Speleol. 2008, 37, 153-172. [CrossRef]

26. Piccini, L. Speleogenesis in highly geodynamic contexts: The Quaternary evolution of Monte Corchia multi-level karst system (Apuan Alps, Italy). Geomorphology 2011, 134, 49-61. [CrossRef]

27. Boccaletti, M.; Elter, P.; Guazzone, G. Plate tectonic models for the development of the western Alps and northern Apennines. Nature 1971, 234, 108-111. [CrossRef]

28. Carmignani, L.; Decandia, A.; Disperati, L.; Fantozzi, L.; Lazzarotto, A.; Liotta, D.; Oggiano, G. Relationships between the Tertiary structural evolution of the Sardinia-Corsica-Provensal Domain and the Northern Apennines. Terra Nova 1995, 7, 128-137. [CrossRef]

29. Elter, P. Introduction à la géologie de l'Appennin septentrional. Bull. Soc. Géol. Fr. 1975, 7, 956-962. [CrossRef]

30. Molli, G.; Meccheri, M. Structural inheritance and style of reactivation at mid-crustal levels: A case study from the Apuan Alps (Tuscany, Italy). Tectonophysics 2012, 579, 74-87. [CrossRef]

31. Pieruccioni, D.; Galanti, Y.; Biagioni, C.; Molli, G. Geology and tectonic setting of the Fornovolasco area, Alpi Apuane (Tuscany, Italy). J. Maps 2018, 14, 357-367. [CrossRef]

32. Vezzoni, S.; Biagioni, C.; D’Orazio, M.; Pieruccioni, D.; Galanti, Y.; Petrelli, M.; Molli, G. Evidence of Permian magmatism in the Alpi Apuane metamorphic complex (Northern Apennines, Italy): New hints for the geological evolution of the basement of the Adria plate. Lithos 2018, 318-319, 104-123. [CrossRef] 
33. Patacca, E.; Scandone, P.; Conti, P.; Mancini, S.; Massa, G. Ligurian-derived olistostrome in the pseudomacigno formation of the stazzema zone (Apuan Alps, Italy). Geological implications at regional scale. Ital. J. Geosci. 2013, 132, 463-476. [CrossRef]

34. Cerrina Feroni, A.; Plesi, G.; Fanelli, G.; Leoni, L.; Martinelli, P. Contributo alla conoscenza dei processi di grado molto basso (anchimetamorfismo) a carico della Falda Toscana nell'area del ricoprimento apuano. Boll. Soc. Geol. Ital. 1983, 102, $269-280$.

35. Kligfield, R.; Hunziker, J.; Dallmeyer, R.D.; Schamel, S. Dating of deformation phases using K-Ar and 40Ar/39Ar techniques: Results from the Northern Apennines. J. Struct. Geol. 1986, 8, 781-798. [CrossRef]

36. Molli, G.; Cortecci, G.; Vaselli, L.; Ottria, G.; Cortopassi, A.; Dinelli, E.; Mussi, M.; Barbieri, M. Fault zone structure and fluid-rock interaction of a high angle normal fault in Carrara marble (NW Tuscany, Italy). J. Struct. Geol. 2010, 32, 1334-1348. [CrossRef]

37. Molli, G.; Torelli, L.; Storti, F. The 2013 Lunigiana (Central Italy) earthquake: Seismic source analysis from DInSar and seismological data, and geodynamic implications for the northern Apennines. A discussion. Tectonophysics 2016, 668-669, 108-112. [CrossRef]

38. Carmignani, L.; Giglia, G. Il problema della doppia vergenza delle Alpi Apuane e la struttura del Monte Corchia. Mem. Soc. Geol. Ital. 1983, 26, 515-525.

39. Carmignani, L.; Conti, P.; Disperati, L.; Fantozzi, P.L.; Giglia, G.; Meccheri, M. Carta Geologica del Parco delle Alpi Apuane 1: 50,000; Carte Geologiche: Firenze, Italy, 2000.

40. Fallani, F.; Piccini, L. Pianta generale del Complesso Carsico del Monte Corchia. Suppl. Talp Riv. Fed. Speleol. Toscana 1990, 2, 10.

41. Molli, G.; Brovarone, A.V.; Beyssac, O.; Cinquini, I. RSCM thermometry in the Alpi Apuane (NW Tuscany, Italy): New constraints for the metamorphic and tectonic history of the inner northern Apennines. J. Struct. Geol. 2018, 113, 200-216. [CrossRef]

42. Conti, P.; Carmignani, L.; Massa, G.; Meccheri, M.; Patacca, E.; Scandone, P.; Pieruccioni, D. Note Illustrative della Carta Geologica d'Italia alla scala 1:50,000 "Foglio 249-Massa Carrara"; ISPRA—Servizio Geologico d'Italia: Roma, Italy, 2019; p. 290.

43. Isola, I.; Mazzarini, F.; Molli, G. Structural analysis in percolating fracture network in karst system: The Antro del Corchia Cave, Alpi Apuane, Italy. In Proceedings of the 28th IUGG Conference on Mathematical Geophysics, Pisa, Italy, 7-11 June 2010.

44. Baldacci, F.; Cecchini, S.; Lopane, G.; Raggi, G. Le risorse idriche del Fiume Serchio ed il loro contributo all'alimentazione dei bacini idrografici adiacenti. Mem. Soc. Geol. Ital. 1993, 49, 365-391.

45. Dickinson, W.R. Interpreting provenance relations from detrital modes of sandstones. In NATO ASI Series (Series C: Mathematical and Physical Sciences); Provenance of Arenites; Zuffa, G.G., Ed.; Springer: Dordrecht, The Netherlands, 1985; Volume 148, pp. 333-361.

46. Zijderveld, J.D.A. AC Demagnetization of Rocks: Analysis of Results. In Methods in Palaeomagnetism; Runcorn, S.K., Creer, K.M., Collinson, D.W., Eds.; Elsevier: Amsterdam, The Netherlands, 1967; pp. 254-286.

47. Butler, R.F. Paleomagnetism: Magnetic Domains to Geologic Terranes; Blackwell Scientific Publications: Portland, OR, USA, 1992; p. 319.

48. Fisher, R. Dispersion on a sphere. Proc. R. Soc. Lond. 1953, A217, 295-305. [CrossRef]

49. Drysdale, R.N.; Zanchetta, G.; Hellstrom, J.C.; Fallick, A.E.; Zhao, J.X.; Isola, I.; Bruschi, G. Palaeoclimatic implications of the growth history and stable isotope $\left(\delta^{18} \mathrm{O}\right.$ and $\left.\delta^{13} \mathrm{C}\right)$ geochemistry of a Middle to Late Pleistocene stalagmite from central-western Italy. Earth Planet. Sci. Lett. 2004, 227, 215-229. [CrossRef]

50. Drysdale, R.N.; Zanchetta, G.; Hellstrom, J.C.; Fallick, A.E.; Zhao, J.X. Stalagmite evidence for the onset of the Last Interglacial in southern Europe at 129+/-1 ka. Geophys. Res. Lett. 2005, 32, 1-4. [CrossRef]

51. Drysdale, R.N.; Zanchetta, G.; Hellstrom, J.C.; Fallick, A.E.; McDonald, J.; Cartwright, I. Stalagmite evidence for the precise timing of North Atlantic cold events during the early last glacial. Geology 2007, 35, 77-80. [CrossRef]

52. Drysdale, R.N.; Zanchetta, G.; Hellstrom, J.C.; Fallick, A.E.; Sanchez-Goni, M.F.; Couchoud, I.; McDonald, J.; Maas, R.; Lohmann, G.; Isola, I. Evidence for obliquity forcing of glacial termination II. Science 2009, 325, 1527-1531. [CrossRef]

53. Drysdale, R.N.; Zanchetta, G.; Baneschi, I.; Guidi, M.; Isola, I.; Couchoud, I.; Piccini, L.; Greig, A.; Wong, H.; Woodhead, J.; et al. Partitioning of $\mathrm{Mg}, \mathrm{Sr}, \mathrm{Ba}$ and $\mathrm{U}$ into a subaqueous calcite speleothem. Geochim. Cosmochim. Acta 2019, 264, 67-91. [CrossRef]

54. Drysdale, R.; Couchoud, I.; Zanchetta, G.; Isola, I.; Regattieri, E.; Hellstrom, J.; Govin, A.; Tzedakis, P.C.; Ireland, T.; Corrick, E.; et al. Magnesium in subaqueous speleothems as a potential palaeotemperature proxy. Nat. Commun. 2020, 11, 1-11. [CrossRef] [PubMed]

55. Zanchetta, G.; Drysdale, R.N.; Hellstrom, J.C.; Fallick, A.E.; Isola, I.; Gagan, M.; Pareschi, M.T. Enhanced rainfall in the western Mediterranean during deposition of sapropel S1: Stalagmite evidence from Corchia Cave (Central Italy). Quat. Sci. Rev. 2007, 26, 279-286. [CrossRef]

56. Zanchetta, G.; Regattieri, E.; Isola, I.; Drysdale, R.N.; Bini, M.; Baneschi, I.; Hellstrom, J.C. The so-called " 4.2 event" in the central Mediterranean and its climatic teleconnections. Alp. Mediterr. Quat. 2016, 29, 5-17.

57. Regattieri, E.; Zanchetta, G.; Drysdale, R.; Isola, I.; Hellstrom, J.; Dallai, L. Late glacial to Holocene trace element record (Ba, Mg, Sr) from Corchia Cave (Apuan Alps, central Italy): Paleoenvironmental implications. J. Quat. Sci. 2016, 29, 381-392. [CrossRef]

58. Bajo, P.; Borsato, A.; Drysdale, R.; Hua, Q.; Frisia, S.; Zanchetta, G.; Hellstrom, J.; Woodhead, J. Stalagmite carbon isotopes and dead carbon proportion (DCP) in a near-closed-system situation: An interplay between sulphuric and carbonic acid dissolution. Geochim. Cosmochim. Acta 2017, 210, 208-227. [CrossRef]

59. Bajo, P.; Drysdale, R.N.; Woodhead, J.D.; Hellstrom, J.C.; Hodell, D.; Ferretti, P.; Voelker, A.; Zanchetta, G.; Rodrigues, T.; Wolff, E.; et al. Persistent influence of obliquity on ice age terminations since the Middle Pleistocene transition. Science 2020, 367, 1235-1239. [CrossRef] 
60. Isola, I.; Zanchetta, G.; Drysdale, R.N.; Regattieri, E.; Bini, M.; Bajo, P.; Hellstromm, J.; Baneschi, I.; Lionello, P.; Woodhead, J.; et al. The 4.2 ka event in the central Mediterranean: New data from a Corchia speleothem (Apuan Alps, central Italy). Clim. Past 2019, 15, 135-151. [CrossRef]

61. Isola, I.; Ribolini, A.; Zanchetta, G.; Bini, M.; Regattieri, E.; Drysdale, R.N.; Hellstrom, J.; Bajo, P.; Montagna, P.; Pons-Branchu, E. Speleothem U/Th age constraints for the Last Glacial conditions in the Apuan Alps, northwestern Italy. Palaeogeogr. Palaeoclimatol. Palaeoecol. 2019, 518, 62-71. [CrossRef]

62. Hellstrom, J. U-Th dating of speleothems with high initial ${ }^{230}$ Th using stratigraphical constraint. Quat. Geochronol. 2006, 1, 289-295. [CrossRef]

63. Woodhead, J.; Hellstrom, J.; Maas, R.; Drysdale, R.; Zanchetta, G.; Devine, P.; Taylor, E. U-Pb geochronology of speleothems by MC-ICPMS. Quat. Geochronol. 2006, 1, 208-221. [CrossRef]

64. Simon, Q.; Bourlès, D.L.; Thouveny, N.; Horng, C.S.; Valet, J.P.; Bassinot, F.; Choy, S. Cosmogenic signature of geomagnetic reversals and excursions from the Réunion event to the Matuyama-Brunhes transition (0.7-2.14 Ma interval). Earth Planet. Sci. Lett. 2018, 482, 510-524. [CrossRef]

65. Channell, J.E.T. Magnetic excursions in the late Matuyama Chron (Olduvai to Matuyama-Brunhes boundary) from North Atlantic IODP sites. J. Geophys. Res. Solid Earth 2017, 122, 773-789. [CrossRef]

66. Frank, M.; Schwarz, B.; Baumann, S.; Kubik, P.W.; Suter, M.; Mangini, A. A 200 kyr record of cosmogenic radionuclide production rate and geomagnetic field intensity from ${ }^{10}$ Be in globally stacked deep-sea sediments. Earth Planet. Sci. Lett. 1997, 149, 121-129. [CrossRef]

67. Piccini, L. Caratteri morfologici ed evoluzione dei fenomeni carsici profondi nelle Alpi Apuane (Toscana-Italia). 1994. Nat. Brescia. 1996, 30, 45-85.

68. Bigazzi, G.; Di Pisa, A.; Gattiglio, M.; Meccheri, M.; Norelli, P. La struttura cataclastico milonitica di foce di Mosceta Alpi Apuane sud-orientali (M. Corchia, Gruppo delle Panie). Atti Soc. Tosc. Sci. Nat. Mem. Ser. A 1988, 95, 105-116.

69. Conti, P.; Di Pisa, A.; Gattiglio, M.; Meccheri, M. The pre-alpine basement in the Apuan Alps (Northern Apennines, Italy). In Pre-Mesozoic Geology in the Alps; Springer Science and Business Media LLC: Berlin/Heidelberg, Germany, 1993 ; pp. 609-621.

70. Puccinelli, A.; D’Amato Avanzi, C.; Perilli, N. Note Illustrative della Carta Geologica d'Italia alla Scala 1:50,000 "Foglio 250—Castelnuovo Garfagna"; ISPRA—Servizio Geologico d'Italia: Roma, Italy, 2019; p. 166.

71. Engel, J.; Woodhead, J.; Hellstrom, J.; Maas, R.; Drysdale, R.; Ford, D. Corrections for initial isotopic disequilibrium in the speleothem U-Pb dating method. Quat. Geochronol. 2019, 54, 101009. [CrossRef]

72. Bennett, R.A.; Serpelloni, E.; Hreinsdóttir, S.; Brandon, M.T.; Buble, G.; Basic, T.; Casale, C.; Cavaliere, A.; Anzidei, M.; Marjonovic, M.; et al. Syn-convergent extension observed using the RETREAT GPS network, northern Apennines, Italy. J. Geophys. Res. 2012, 117, B04408. [CrossRef]

73. Piccini, L. Evolution of karst in the Apuan Alps (Italy): Relationships with the morphotectonic history. Suppl. Geogr. Fis. Din. Quat. 1998, III-4, 21-31. 